\title{
Pedofilia we Włoszech: skala problemu, aspekty etyczne i ochrona nieletnich
}

\author{
Andrzej Kobyliński \\ Wydział Filozofii Chrześcijańskiej, Uniwersytet Kardynała Stefana Wyszyńskiego \\ ul. Wóycickiego 1/3, 01-938 Warszawa \\ a.kobylinski@uksw.edu.pl
}

\section{Streszczenie}

W ostatnich latach rozwija się na całym świecie plaga pedofilii, która stała się nową formą niewolnictwa w wymiarze globalnym. Z jednej strony, w wielu krajach są podejmowane różnego rodzaju inicjatywy polityczne i społeczne, których głównym celem jest walka z wykorzystywaniem seksualnym osób nieletnich, z drugiej - Internet i nowoczesne technologie informatyczne dają pedofilom radykalnie nowe możliwości, gdy chodzi o kontakt z dziećmi w świecie wirtualnym czy dystrybucję materiałów pedopornograficznych. Włochy są jednym z wielu państw, w których pedofilia stała się ostatnio przedmiotem żywego zainteresowania opinii publicznej. Głównym celem badań podjętych w tym artykule jest analiza przyczyn i specyfiki wykorzystywania seksualnego dzieci w kraju nad Tybrem oraz ukazanie najważniejszych aspektów etycznych tego zjawiska.

\section{Słowa kluczowe}

pedofilia, wykorzystywanie seksualne dzieci, pedopornografia, rewolucja seksualna, sexting, efebofilia, prawa dzieci, przemoc seksualna, ochrona nieletnich

\section{Wprowadzenie}

5 maja 2017 roku obchodzono we Włoszech, po raz pierwszy w historii tego kraju, Narodowy Dzień Walki z Pedofilią (Giornata nazionale per la lotta alla pedofilia). Głównym celem tej inicjatywy było większe uwrażliwienie opinii publicznej na nowe formy molestowania seksualnego osób nieletnich i różne rodzaje pornografii dziecięcej. W ramach tych obchodów zorganizowano we Włoszech wiele dyskusji panelowych, konferencji prasowych, spotkań poświęconych pladze wykorzystywania seksualnego dzieci oraz adekwatnym formom terapii, adresowanej do ofiar pedofilów. Tego rodzaju inicjatywy budzą niewątpliwie głębszą wrażliwość moralną społeczeństwa włoskiego i tworzą nową świadomość opinii publicznej w tym kraju.

Najnowsze badania prowadzone w ojczyźnie Dantego wykazują jednoznacznie, że molestowanie seksualne dzieci przez osoby dorosłe jest od wielu lat poważnym problemem społecznym. Oficjalne dane mówią o tym, że każdego roku ofiarami pedofilów staje się ok. 21 tys. osób nieletnich. We Włoszech 65\% wszystkich ofiar pedofilii stanowią dziewczynki, 35\% chłopcy. W siedmiu przypadkach na dziesięć ofiara zna swego oprawcę - oznacza to, że znakomita 
większość przypadków molestowania seksualnego nieletnich dokonuje się w kręgu krewnych i znajomych (por. Felix 2016).

Dramat włoskich dzieci, wykorzystywanych seksualnie, jest małą częścią wielkiej plagi o charakterze globalnym. Ofiarami pedofilii i pedopornografii są dzisiaj miliony osób nieletnich na wszystkich kontynentach. W obecnym stuleciu molestowanie seksualne dzieci stało się straszną plagą, która występuje w przestrzeni życia rodzinnego, społecznego czy zawodowego. W ostatnich latach opublikowano na świecie wiele cennych opracowań na temat zjawiska pedofilii, które ukazują ten bolesny i wstydliwy dramat jako wielki problem moralny, filozoficzny, społeczny czy wychowawczy (por. Kramer 2017; Kershnar 2017; McNamara 2016; Frassi 2011; Sero 2007; Guenzi 2004).

Na czym polega istota wykorzystywania seksualnego osób nieletnich? Jak określić istotę pedofilii? Bolesne i wstydliwe zjawisko molestowania seksualnego dzieci może przybierać różne formy. Zasadniczo pedofilia oznacza każdy rodzaj zainteresowania seksualnego, trwałego i powtarzającego się - nawet na poziomie fantazji - ze strony osoby dorosłej w stosunku do dzieci. „Pedofilia może mieć charakter heteroseksualny, homoseksualny bądź biseksualny. Gdy mówimy o pedofilii w sensie szerokim, mamy na uwadze wykorzystywanie seksualne dzieci i młodzieży poniżej 18. roku życia. Natomiast pedofilia w sensie ścisłym dotyczy molestowania seksualnego dzieci przed okresem dojrzewania. Wykorzystywanie małoletnich w wieku 12-18 lat jest nazywane efebofilią. Pedofilia czy efebofilia były znane już w czasach starożytnych, choć bardzo często nie postrzegano takich zachowań seksualnych jako nagannych moralnie" (Kobyliński 2017b, 44).

Niestety, w ostatnich latach badania naukowe pokazują gwałtowny rozwój pedofilii w wielu krajach. Najważniejszą przyczyną tendencji wzrostowej zjawiska molestowania seksualnego dzieci jest obecnie wykorzystywanie przez pedofilów niezwykłych możliwości technicznych Internetu, który ułatwia im nawiązywanie kontaktu z ofiarami oraz umożliwia łatwy dostęp do pornografii dziecięcej (por. Buono, De Luca 2015). Najnowszy etap rozwoju tego fenomenu polega na tym, że pedofilia staje się nie tyle formą molestowania seksualnego w przestrzeni życia rodzinnego czy towarzyskiego, ile wykorzystywaniem dzieci zorganizowanym w wymiarze światowym, np. w ramach tzw. turystyki seksualnej do krajów Azji czy Ameryki Południowej.

W jaki sposób pedofilia rozwinęła się w społeczeństwie włoskim? Jaki wpływ na rozwój molestowania seksualnego dzieci miała „omertà”, czyli zmowa milczenia w przestrzeni życia społecznego, politycznego i rodzinnego? Co mówią najnowsze raporty o skali wykorzystywania seksualnego osób nieletnich? Jakie organizacje non-profit zajmują się w kraju nad Tybrem ochroną i promocją praw dziecka? W jaki sposób społeczeństwo obywatelskie we Włoszech walczy z plagą pedofilii?

Głównym celem badań podjętych w tym artykule jest analiza przyczyn i specyfiki seksualnego wykorzystywania dzieci we Włoszech oraz ukazanie najważniejszych aspektów etycznych tego zjawiska.

\section{Przemoc seksualna we wloskim systemie prawnym}

Obowiązujące obecnie prawo w kraju nad Tybrem uznaje za przestępstwo różne formy przemocy seksualnej. Głęboka reforma w tym zakresie została przeprowadzona w 1996 roku, gdy do włoskiego Kodeksu Karnego wprowadzono nowe przepisy dotyczące przemocy seksualnej. Nowa regulacja z 1996 roku odróżniła przestępstwo wykorzystania seksualnego osoby nieletniej, w którym wystąpiła zgoda dziecka na takie zachowanie, od aktów seksualnych, którym towarzyszyły różne formy przymusu.

We Włoszech wiek zgody osoby nieletniej na dobrowolne relacje seksualne $\mathrm{z}$ osoba pełnoletnią jest określony na poziomie 14 lat. Jeśli dziecko ukończyło 14, lat, może utrzymywać dobrowolne relacje seksualne $\mathrm{z}$ osobami powyżej 18. roku życia. Dolna granica 
wieku obniża się natomiast do 13 lat, jeśli obydwoje partnerzy są nieletni, a różnica wieku między nimi nie przekracza trzech lat. Wiek zgody podnosi się jednak do 16. roku życia, gdy jeden z partnerów ma jakąś formę władzy wobec drugiego - jest np. nauczycielem, katechetą, instruktorem harcerskim, wychowawcą czy trenerem sportowym. Wiek zgody podnosi się do 18. roku życia, gdy jeden z partnerów jest rodzicem adoptowanym, tutorem lub krewnym.

W 1998 roku weszła w życie w ojczyźnie Dantego tzw. ustawa antypedofilska, która uregulowała problemy związane z nowymi formami prostytucji dziecięcej, pedopornografii, turystyki seksualnej i innych form redukowania dzieci do poziomu współczesnych niewolników. Włoska „ustawa antypedofilska” z końca lat 9o. ubiegłego wieku została częściowo zmieniona w 2006 roku. Czego dotyczyły wprowadzone zmiany? Ustawodawcy chodziło głównie o dopasowanie przepisów obowiązujących obecnie w kraju nad Tybrem do najnowszych umów międzynarodowych i prawa Unii Europejskiej. Przede wszystkim zostały zaostrzone kary za różnego rodzaju przestępstwa seksualne, których ofiarami są osoby nieletnie. W aktualnie obowiązującej wersji „ustawy antypedofilskiej” poszerzono także pojęcie pornografii dziecięcej i podwyższono granicę wieku dla ofiar prostytucji dziecięcej z 16 do 18 lat.

Obowiązujący obecnie we Włoszech Kodeks Karny definiuje w art. 609 przemoc seksualną jako przestępstwo, w którym sprawca zmusza ofiarę - przez przemoc, groźbę lub wykorzystanie relacji zależności służbowej - do podjęcia aktów seksualnych. Do przemocy seksualnej dochodzi również wówczas, gdy sprawca aktów seksualnych wykorzystuje swoją przewagę fizyczną lub psychiczną nad ofiarą. Wiek ofiary zalicza się do okoliczności obciążających. Sprawca takich czynów nie może powoływać się w swojej obronie na nieznajomość tego rodzaju przepisów prawa. Okoliczności obciążające obejmują konkretnie następujące sytuacje: a. jeśli przestępstwo zostało popełnione przeciwko osobie, która w chwili zdarzenia nie ukończyła czternastego roku życia;

b. jeśli ofiara nie osiągnęła szesnastego roku życia, a sprawca jest rodzicem biologicznym, rodzicem adopcyjnym lub opiekunem;

c. jeśli przestępstwo zostało popełnione przeciwko dziecku, które nie ukończyło dziesięciu lat.

W 2006 roku włoski ustawodawca wprowadził także do Kodeksu Karnego pojęcie uwodzenia osób nieletnich - chodzi tutaj o każdą czynność ukierunkowaną na zdobycie zaufania dziecka, od pochlebstwa do zastraszenia, także w przestrzeni internetowej czy przy wykorzystaniu innych środków masowej komunikacji. Prawo włoskie przewiduje karanie swoich obywateli za przestępstwa związane z prostytucją i pornografią dziecięcą, jeśli nawet zostały one popełnione za granicą. Osoby skazane za pedofilię mogą też otrzymać dożywotni zakaz pracy w szkołach, klubach sportowych, biurach oraz innych strukturach publicznych i prywatnych, które są odwiedzane głównie przez dzieci i młodzież.

W 2012 roku dokonano we Włoszech ratyfikacji Konwencji Rady Europy o ochronie dzieci przed wykorzystywaniem seksualnym i niegodziwym traktowaniem w celach seksualnych, przyjętej na wyspie Lanzarote - na jednej z siedmiu głównych wysp wchodzących w skład archipelagu Wysp Kanaryjskich - w dniu 25 października 2007 roku. Konwencja z Lanzarote jest obecnie najważniejszym dokumentem międzynarodowym, mającym na celu zagwarantowanie ochrony dzieci przed różnymi formami pedofilii. Konwencja Rady Europy ma przede wszystkim chronić dzieci oraz usprawnić współpracę międzynarodową w zakresie przeciwdziałania przemocy seksualnej i rozpowszechniania pornografii dziecięcej.

Wraz z ratyfikacją Konwencji z Lanzarote, włoski parlament dokonał zmiany w Kodeksie Karnym, do którego wprowadzono mocą ustawy nr 172/2012 - artykuł 414 bis. 
W ten sposób po raz pierwszy we włoskim systemie prawnym znalazła się kategoria „pedofilii i pedopornografii kulturowej”. W tym przypadku Konwencja Rady Europy została wykorzystana przede wszystkim jako narzędzie do walki z ideologią pedofilii i różnymi formami jej promocji. Obecnie włoskie prawo stanowi, że każdy, kto w jakikolwiek sposób - także przy użyciu technik telematycznych lub jedynie w celach kulturowych - publicznie usprawiedliwia, promuje czy zachęca do praktykowania jakichkolwiek form relacji seksualnych między osobami dorosłymi i małoletnimi, podlega karze więzienia do lat trzech.

Niestety, pomimo wejścia w życie Konwencji z Lanzarote, także dzisiaj mamy do czynienia z promocją pedofilii w wymiarze globalnym. Ciągle na wielu stronach internetowych można spotkać np. loga czy symbole środowisk pedofilskich, które umożliwiają internautom identyfikację własnych preferencji seksualnych i wskazują preferowaną płeć nieletnich ofiar. Liderzy organizacji pedofilskich zachęcają do stosowania trzech znaków graficznych, które odpowiadają trzem preferowanym kategoriom potencjalnych ofiar: „boylove”, girlove" i „childlove”.

Warto w tym miejscu podkreślić, że ważną włoską agendą rządową, funkcjonującą przy Departamencie Równych Szans Rady Ministrów, jest Narodowe Obserwatorium ds. Walki z Pedofilią i Pornografią Dziecięcą (Osservatorio Nazionale per il contrasto della pedofilia e della pornografia minorile). Obserwatorium zostało założone w 2006 roku. Członkami tej instytucji są przedstawiciele różnego rodzaju organizacji i stowarzyszeń, które zajmują się we Włoszech problemem seksualnego wykorzystywania osób nieletnich - m.in. Stowarzyszenie Meter oraz Stowarzyszenie Niebieski Telefon.

Jaki jest główny cel działalności Narodowego Obserwatorium? Najważniejsze jest pozyskiwanie informacji oraz monitorowanie danych dotyczących działalności władz publicznych, gdy chodzi o zapobieganie pedofilii, karanie za takie czyny i prewencję dotyczącą jakichkolwiek form wykorzystywania seksualnego nieletnich. Członkowie tej agendy rządowej zajmują się także koordynacją różnych inicjatyw, podejmowanych w tym zakresie na terytorium Włoch oraz pozostających w zgodzie z prawem międzynarodowym i standardami Unii Europejskiej. Ważnym zadaniem tej jednostki jest także proponowanie odpowiednich zmian legislacyjnych oraz tworzenie baz danych dotyczacych pedofilii i pornografii dziecięcej.

Obserwatorium jest kierowane obecnie przez szefa Departamentu Równych Szans Rady Ministrów. W skład tej agendy rządowej wchodzą m.in. koordynator naukowo-techniczny, przedstawiciele Departamentu ds. Polityki Rodzinnej, Policji Państwowej, Karabinierów, Policji Finansowej i Ministerstwa Sprawiedliwości. Wśród członków Obserwatorium, powoływanych przez władze rządowe, jest także czterech przedstawicieli wyznaczonych przez stowarzyszenia krajowe, najbardziej reprezentatywne w zakresie zwalczania zjawiska pedofilii i różnych form wykorzystywania seksualnego nieletnich.

\section{Pedofilia według Stowarzyszenia Meter}

We Włoszech pogłębione badania naukowe nad fenomenem wykorzystywania seksualnego dzieci zostały podjęte de facto dopiero w ostatnich latach (por. Di Gregorio 2016). Pionierem w prowadzeniu takich badań na świecie są niewątpliwie Stany Zjednoczone, gdzie przedstawiciele różnych dyscyplin naukowych zajmują się tym problemem od lat 70. ubiegłego wieku (por. DeMause 1998). Dzięki rozpoczęciu badań nad pedofilią w społeczeństwie włoskim, także w ojczyźnie Dantego zaczęły się ukazywać ciekawe książki i artykuły poświęcone temu zagadnieniu. Na przestrzeni ostatnich kilku lat można mówić o wielkim przebudzeniu moralnym, jakie nastąpiło w kraju nad Tybrem wobec zjawiska molestowania seksualnego dzieci.

Wielką rolę w tym względzie odegrała jedna $z$ organizacji non-profit o nazwie Stowarzyszenie Meter Onlus (Associazione 
Meter Onlus), która została założona w 1989 roku na Sycylii w celu promocji praw dzieci i ochrony osób nieletnich. Warto w tym miejscu dodać, że słowo „meter” pochodzi z języka greckiego i oznacza w języku medycznym macicę, natomiast w sensie szerszym odnosi się także do działań i zachowań ukierunkowanych na ochronę, opiekę i towarzyszenie. Założycielem tej organizacji non-profit jest włoski duchowny katolicki Fortunato Di Noto - znany działacz na rzecz ochrony małoletnich przed wykorzystywaniem seksualnym, który w bardzo ostry sposób nazywa pedofilię cichym holokaustem (olocausto silenzioso) XXI wieku (por. Di Noto 2002). Do tego niezwykle mocnego porównania nawiązuje m.in. włoski pisarz i dziennikarz Ferruccio Pinotti, który używa wyrażenia biały holokaust (olocausto bianco) na określenie współczesnej plagi pedofilii (por. Pinotti 2008).

Stowarzyszenie Meter prowadzi szeroko zakrojoną działalność edukacyjną, szkoleniową, prewencyjną, publicystyczną itp. W 2016 roku działacze tej organizacji non-profit zajęli się bezpośrednio 91 ofiarami pedofilii, udzielili 1.157 konsultacji telefonicznych o charakterze psychologicznym i duchowym. Od września 2016 roku funkcjonuje nowa usługa - Centrum Wielofunkcyjne Dzieci, Młodzieży i Autyzmu, które koncentruje się na szybkiej reakcji i wykorzystywaniu najnowszych technologii. Działacze Stowarzyszenia Meter organizują spotkania w szkołach, różnego rodzaju kursy i szkolenia poświęcone walce z pedofilią, przygotowują odpowiednie materiały szkoleniowe, współpracują z organami ścigania. W latach 2003-2016 Meter przekazało włoskiej Policji Pocztowej (Polizia postale) dane dotyczące 134.74.4 stron internetowych zawierających materiały pedopornograficzne.

$\mathrm{Z}$ inicjatywy tej organizacji non-profit, na przełomie kwietnia i maja 2017 roku obchodzono we Włoszech XXI Dzień Dzieci, które są Ofiarami Przemocy, Wykorzystania i Obojętności wobec Pedofilii. Obchody rozpoczęto w miejscowości Avola na Sycylii, w prowincji Syrakuzy, gdzie znajduje się główna siedziba Stowarzyszenia Meter. Obchody odbywają się raz w roku i trwają zawsze od 24 kwietnia do pierwszej niedzieli maja. Od ponad 20 lat ten Dzień ma swoje umocowanie prawne w odpowiedniej ustawie Regionu Sycylii i dodatkowo posiada patronat obydwu izb włoskiego parlamentu. Obchody mają miejsce przede wszystkim w placówkach Stowarzyszenia Meter, rozsianych na terenie całego kraju. W ramach obchodów są organizowane spotkania edukacyjne i religijne, gry i zabawy dla dzieci, projekcje filmów, pogadanki, panele dyskusyjne itp.

Warto w tym miejscu wyraźnie podkreślić, że najważniejszą formą działalności tej organizacji non-profit jest monitorowanie Internetu pod kątem różnych form wykorzystywania seksualnego dzieci i pedopornografii. Do realizacji tego zadania Stowarzyszenie Meter wykorzystuje najnowocześniejsze urządzenia techniczne, które pozwalają przeglądać wirtualne archiwa pedofilskie - także w tzw. ciemnym, ukrytym lub głębokim Internecie, określanym najczęściej jako Darknet lub Deepweb. To właśnie ta część Internetu, nieznana i niedostępna dla większości użytkowników, staje się od kilku lat prawdziwym rajem dla pedofilów. Dlaczego? Ponieważ treści zamieszczonych w przestrzeni Deepweb nie można znaleźć przy pomocy standardowych wyszukiwarek, dla których ukryta Sieć pozostaje niewidoczna.

20 marca 2017 roku w miejscowości Avola na Sycylii miała miejsce prezentacja Raportu 2016 (por. Associazione Meter Onlus 2017). Coroczne raporty, publikowane od wielu lat przez działaczy Meter, stanowią prawdziwą kopalnię wiedzy na temat skali zjawiska pedofilii we Włoszech oraz w wymiarze globalnym. Co stanowi nowość Raportu 2016 w porównaniu z Raportem 2015? Najważniejsza zmiana dotyczy gwałtownego wzrostu liczby różnego rodzaju materiałów pedofilskich i pedopornograficznych w Deepweb oraz coraz większe zainteresowanie pedofilów noworodkami w przedziale 
wiekowym o-3 (por. Bellaspiga 2015a; Bellaspiga 2015b).

Perwersja klientów pornografii dziecięcej domaga się materiałów z udziałem coraz młodszych dzieci poniżej trzeciego roku życia. W konsekwencji mamy do czynienia z gwałtownym wzrostem pedopornografii z udziałem dzieci w przedziale wiekowym o-3. Wytwarzanie materiałów pornografii dziecięcej oraz realne akty molestowania seksualnego dotyczą coraz młodszych dzieci - im młodsi są chłopcy i dziewczynki, tym bardziej cenny „towar” stanowią dla pedofilów, którzy szukają możliwie najmłodszych ofiar.

Z Raportu 2016 wynika, że w ostatnim okresie nastąpił poważny wzrost liczby dostępnych w Internecie zdjęć pornografii dziecięcej: w 2016 roku działacze Meter zidentyfikowali 1.946.898 takich materiałów, natomiast rok wcześniej było ich 1.180.909. Gdy chodzi o filmy pornograficzne z udziałem dzieci, nastąpił aż trzykrotny wzrost: $76.200 \mathrm{w} 2015 \mathrm{roku}, 203.047 \mathrm{w} 2016$ roku. Warto zauważyć, że za każdym wykorzystaniem seksualnym „wirtualnym” (zdjęciem czy filmem pornograficznym z udziałem dzieci) mamy konkretne osoby nieletnie z krwi i kości, których cierpienie woła do naszych sumień. Bardzo często te same dzieci są wykorzystywane do wytwarzania materiałów pornograficznych na przestrzeni wielu lat. Oznacza to, że są one de facto niewolnikami producentów pedopornografii i przeżywają swoje dzieciństwo w klimacie deprawacji i całkowitego uzależnienia. W takich przypadkach winę moralną ponoszą nie tylko wytwórcy takich materiałów i odpowiedzialni za ich dystrybucję, ale także ci wszyscy, którzy w zaciszu swoich domów czy miejsc pracy szukają w Internecie takich materiałów i stwarzają zapotrzebowanie na produkcję tego rodzaju filmów i zdjęć.

Pedofile wykorzystują coraz częściej także platformy telematyczne (por. Associazione Meter Onlus 2017, 26-27). Zdecydowanie największy wzrost dotyczy przestrzeni Cloud, która umożliwia gromadzenie plików i ich tymczasową wymianę - pedofile wykorzystują szczególnie usługę iCloud, którą oferuje amerykański koncern technologiczny Apple. W 2015 roku w przestrzeni iCloud zostało zidentyfikowanych 80 materiałów pornografii dziecięcej, rok później już 574. Poważny wzrost liczby materiałów pedofilskich i pedopornograficznych dotyczy także takich platform telematycznych, jak Dropbox (umożliwia posiadanie przy sobie w każdym zakątku świata zdjęć, dokumentów i filmów oraz ich łatwą wymianę - do każdego pliku zachowanego w Dropbox można mieć dostęp poprzez komputer, telefon, tablet i stronę internetową tej platformy), Box.com (usługa Cloud, która pozwala mieć zawsze do dyspozycji własne materiały elektroniczne i umożliwia korzystanie z nich niezależnie od miejsca i czasu) oraz Mega (usługa typu Cloud stosowana do szyfrowania digitalnego, która jest wykorzystywana w celach komercyjnych, ale może służyć także do ukrywania materiałów pornografii dziecięcej; dostęp do danych w chmurze Mega ma tylko i wyłącznie użytkownik).

Gdy chodzi o poszczególne kraje ujęte w omawianym Raporcie, w 2016 roku prawdziwa eksplozja pedofilii nastąpiła w niewielkim Królestwie Tonga, które leży w Polinezji na południowym Pacyfiku, między Nową Zelandią a Hawajami (por. Associazione Meter Onlus 2017, 12-19). Na serwerach internetowych zarejestrowanych w tym małym państwie, które ma 100.00o mieszkańców, w 2016 roku zidentyfikowano aż 4.156 materiałów dotyczących pedofilii i pornografii dziecięcej, podczas gdy rok wcześniej było ich „tylko” 504. W tym przypadku mamy aż ośmiokrotny wzrost na przestrzeni dwunastu miesięcy. Nie chodzi tutaj bynajmniej o mieszkańców tego kraju, ale o pedofilów z innych państw, którzy wykorzystują dla swoich celów domeny internetowe rejestrowane w Królestwie Tonga. Jeśli w danym kraju nie ma odpowiedniej kontroli Internetu, jeśli nie ma właściwych organów ścigania i możliwości identyfikacji sprawców molestowania seksualnego dzieci, to takie państwo staje się bardzo szybko 
prawdziwym rajem dla pedofilów z całego świata.

W Raporcie 2016 drugie miejsce po Królestwie Tonga zajęła Rosja (635), a trzecie Nowa Zelandia (312). To trzy państwa umieszczone na swego rodzaju podium wstydu. Gdy chodzi o poszczególne kontynenty, sytuacja wygląda następująco: Europa - Rosja (635), Słowacja (111) i pozostałe państwa Unii Europejskiej (66); Ameryka Północna i Południowa - Kolumbia (22), Grenlandia (16) i Kanada (4); Azja - Indie (56), Iran (16) i Japonia (5); Afryka - Libia (167), Gabon (43) i Mauritius (32); Australia i Oceania - Królestwo Tonga (4.156), Nowa Zelandia (312) i Palau (62). Gdy chodzi o podium wstydu wszystkich kontynentów Raportu 2016, sytuacja wygląda następująco: Australia i Ocenia (4.613), Europa (868) i Afryka (259).

Niestety, szokujące informacje zawarte w Raporcie Stowarzyszenia Meter znajduja potwierdzenie w ustaleniach operacyjnych włoskiej Policji Pocztowej. Co pewien czas opinia publiczna w kraju nad Tybrem jest informowana o aresztowaniu pedofilów lub rozbiciu międzynarodowych grup przestępczych, zajmujących się prostytucją dziecięcą czy pedopornografią. Policja Pocztowa potwierdza, że pedofilia przenosi się do Darknetu. Oficjalne dane włoskich organów ścigania mówią o tym, że w głębokim Internecie tworzą się różnego rodzaju wspólnoty złożone z tysięcy pedofilów, którzy utrzymują między sobą łączność telematyczną, wymieniają się materiałami pedopornograficznymi, prowadzą między sobą dyskusje na tematy związane $\mathrm{z}$ relacjami seksualnymi między osobami dorosłymi i nieletnimi.

\section{Darknet - ciemna strona Sieci}

Podczas oficjalnej prezentacji Raportu 2016 Fortunato Di Noto potwierdził, że w ukrytym Internecie istnieje m.in. portal pedofilski „tylko i wyłącznie z noworodkami, który ma chatroom z dialogami w języku włoskim" (Bellaspiga 2017). Na tym portalu umieszczono wiele zarejestrowanych przypadków gwałtów na noworodkach. Z tych strasznych materiałów korzystają pedofile z wielu krajów świata. Międzynarodowa sieć pedofilów jest dobrze zorganizowaną grupą przestępczą, gdy chodzi o wytwarzanie i dystrybucję pedopornografii oraz wzajemną pomoc w znajdowaniu odpowiednich ofiar, które zaspokoją ich chore pragnienia seksualne.

Warto jeszcze raz stanowczo podkreślić, że pedofilia przenosi się coraz bardziej do głębokiego Internetu. W tej mrocznej przestrzeni internetowej pedofile czują się bezpieczni dzięki szyfrowaniu informacji. W ten sposób zachowują anonimowość - w konsekwencji w Darknet dzieją się najbardziej makabryczne rzeczy. W ukrytej przestrzeni internetowej ma miejsce brutalna i tragiczna w skutkach przestępczość: wymiana informacji między pedofilami na temat skutecznych sposobów nakłaniania i uwodzenia dzieci, wytwarzanie i dystrybucja pedopornografii, tworzenie archiwów z materiałami pornografii dziecięcej, wymiana własnych doświadczeń dotyczących relacji seksualnych osób dorosłych z dziećmi itp. Niektóre badania pokazują, że Darknet może być kilkakrotnie większy niż Sieć zewnętrzna, czyli zwykły Internet.

Jak funkcjonuje Deepweb? Równolegle do normalnego Internetu istnieje ciemna strona Sieci, w której handluje się materiałami wybuchowymi, bronią, narkotykami czy materiałami pornograficznymi. Światowa opinia publiczna dowiedziała się szerzej o istnieniu tej formy Internetu zasadniczo po strzelaninie w Monachium, która miała miejsce 22 lipca 2016 roku. Wówczas okazało się, że zamachowiec kupił sobie broń palną właśnie w ciemnym Internecie - zwykłym kliknięciem, tak samo jak kupuje się różne artykuły w zupełnie normalnym sklepie internetowym.

Tajemniczy Darknet jest w pierwszej kolejności zbiorczą nazwą określającą różne anonimowe strony internetowe, sklepy, fora dyskusyjne i inne serwisy dostępne w Internecie, które - w przeciwieństwie do zwykłych stron internetowych - nie są dostępne przez adres www. To sieć ukryta dla popularnych wyszukiwarek takich jak 
Google, Bing czy Yahoo. Witryny w ukrytym Internecie - anonimowe strony internetowe, sklepy, serwisy, fora, portale - maja rozszerzenie w domenie .onion. Zapewnia to oglądającym potencjalnie większą anonimowość. Materiały zgromadzone w ukrytym Internecie istnieją jakby w podziemiu, a osoby wtajemniczone przekazują sobie adresy odpowiednich stron; można je też znaleźć w specjalnych wyszukiwarkach (na przykład Grams). Użytkownicy głębokiego Internetu korzystają z powszechnie dostępnych narzędzi, jak na przykład przeglądarka wirtualnej sieci TOR.

Z Raportu 2016 Stowarzyszenia Meter wynika, że zmniejsza się ostatnio aktywność pedofilów w mediach społecznościowych. Gdy chodzi o takie portale jak Twitter, Facebook czy Youtube, w 2016 r. Stowarzyszenie Meter zidentyfikowało 155 materiałów zawierających treści pedofilskie, podczas gdy rok wcześniej takich przypadków było 3.414. Niestety, to nie jest dobra wiadomość dla dzieci i osób walczących z pedofilią. Dlaczego? Ponieważ pedofile wybierają coraz bardziej wyrafinowane formy wymiany i dystrybucji materiałów pornografii dziecięcej - przenoszą się właśnie do Darknet, gdzie stają się praktycznie niewidzialni, nieuchwytni i prawie całkowicie bezkarni (por. Associazione Meter Onlus 2017, 20-25). Prezentując Raport 2016, Fortunato Di Noto stwierdził, że to zjawisko „rozwija się dramatycznie szybko i coraz trudniej służbom porządkowym zwalczać plagę planetarną, która jest kontrolowana przez potężne organizacje kryminalne" (Bellaspiga 2017).

Z Raportu 2016 Stowarzyszenia Meter wynika, że pedofile stosują coraz częściej usługę Dropfile, która umożliwia wymianę czasową plików - wystarczy umówić się wirtualnie na wybranym czacie na jednym z odpowiednich serwerów, aby udostępnić materiały pedopornograficzne na określony czas - maksymalnie 24 godziny. Następnie wszystko podlega samozniszczeniu, nie zostawiając żadnych śladów. Jest to metoda podobna do technik prezentowanych w niektórych filmach szpiegowskich, gdy chodzi o przechwytywanie cennych informacji. Techniki podobne do usługi Dropfile stosują m.in. dilerzy handlujący narkotykami.

Działacze Stowarzyszenia Meter zidentyfikowali w Deepweb także włoskie adresy telematyczne związane $\mathrm{z}$ pedofilią i pornografią dziecięcą, których liczba wzrosła z 70 w 2015 roku do 95 w 2016 roku. Systemem najczęściej stosowanym w Deepweb jest The Onion Router (TOR) - sieć komunikacyjna, która funkcjonuje na zasadzie autonomii swoich członków, chronionych przez specjalne systemy szyfrowania. System TOR został stworzony po to, aby zagwarantować najwyższy poziom bezpieczeństwa osobom, które z niego korzystają. W konsekwencji jest bardzo trudno ustalić numer IP, przypisany każdemu komputerowi, który łączy się z Siecią. Nie jest przypadkiem nazwanie techniki TOR właśnie cebulą (ang. onion) symbol cebuli, która ma warstwy, wskazuje różne poziomy (warstwy) tajności i poufności, które obejmują użytkowników tego systemu.

Niestety, dzisiaj system TOR jest stosowany najczęściej do działań nielegalnych takich jak chociażby pedofilia. Organom ścigania nie jest łatwo zatrzymać tych, którzy korzystają z tej technologii. Siłę rażenia tego systemu w obrębie pedofilii dobrze oddaje konkretny przykład, zawarty w Raporcie 2016. Otóż w listopadzie 2016 roku specjaliści Stowarzyszenia Meter zidentyfikowali w systemie TOR specjalny portal, na którym było umieszczonych 82.046 filmów pornograficznych z udziałem dzieci. Materiały pedopornograficzne $\mathrm{z}$ tego portalu zostały pobrane przez 476.914 użytkowników. Co więcej, organom ścigania nie udało się zlikwidować tej domeny zarejestrowanej w głębokim Internecie. Gdy specjaliści Stowarzyszenia Meter zidentyfikowali ponownie ten portal 10 marca 2017 roku, zawierał on już 109.535 filmów pornografii dziecięcej, pobranych przez 685.590 użytkowników. Ten przykład pokazuje bardzo wyraźnie, jak łatwy jest dostęp do pedopornografii w Deepweb oraz jak trudno ustalić dane 
personalne pedofilów, żeglujących w niewidzialnej przestrzeni Darknet.

Wstrząsające ustalenia działaczy Stowarzyszenia Meter znajdują potwierdzenie m.in. w wynikach spektakularnej akcji antypedofilskiej, przeprowadzonej przez australijskie organy ścigania w latach 2016-2017. Na początku października 2017 roku media na całym świecie szeroko informowały o działaniach policji australijskiej w walce z pedofilią w przestrzeni cyfrowej. Australijskim stróżom prawa ze specjalnej grupy operacyjnej "Agros”, powołanej do walki z pedofilią online, udało się przejąć największy ze znanych dotychczas serwisów z pornografią dziecięcą, funkcjonujący w Darknecie, o nazwie Childs Play. Działania operacyjne doprowadziły do zidentyfikowania danych użytkowników tego serwisu z treściami pedofilskimi. $\mathrm{Na}$ tym specjalnym portalu dla pedofilów było zarejestrowanych blisko milion kont.

Wielka operacja policyjna trwała cały rok. Przejęcie Childs Play rozpoczęło się w październiku 2016 roku od namierzenia i zatrzymania dwóch pedofilów: Kanadyjczyka Benjamina Faulknera i Amerykanina Patricka Falte'a, którzy wspólnie stworzyli ten serwis w kwietniu 2016 roku. Sąd skazał ich na dożywocie, a policjanci zwalczający pedofilię przejęli konta obu pedofilów i w ten sposób uzyskali dostęp do bazy danych portalu. Policja australijska, współpracując z europejskimi i amerykańskimi organami ścigania, przez cały rok „kontynuowała” działalność Faulknera i Falte'a, a liczba użytkowników serwisu z całego świata ciągle rosła. Gdy ostatecznie policja zamknęła Childs Play na początku października 2017 roku, liczba użytkowników osiągnęła milion.

\section{Raport Stowarzyszenia Niebieski Telefon}

Kolejną niezwykle ważną organizacją non-profit, zajmującą się obecnie we Włoszech problemem wykorzystywania seksualnego dzieci, jest Stowarzyszenie Niebieski Telefon (Associazione Telefono Azzurro). Organizacja została założona w 1987 roku w Bolonii przez Ernesta Caffo, profesora neuropsychiatrii dziecięcej na Uniwersytecie Modeny i Reggio Emilia. Jej głównym celem statutowym jest szeroko rozumiana ochrona praw dzieci. Stowarzyszenie posiada dwie profesjonalne linie telefoniczne: Telefon Zaufania - 1.96.96 oraz Telefon Ratunkowy - 114 . Telefony służą przede wszystkim osobom nieletnim, które mogą zgłaszać swoje problemy działaczom tej organizacji non-profit.

Z Telefonu Zaufania i Telefonu Ratunkowego korzystają także dorośli (rodzice, nauczyciele, pedagodzy, pracownicy socjalni, wychowawcy itp.), którzy chcą przekazać informacje dotyczące przypadków stosowania przemocy wobec dzieci i szukają najlepszych form pomocy nieletnim, skrzywdzonym w różny sposób lub zagrożonym naruszeniem ich praw. Telefon Ratunkowy jest dostępny 24 godziny na dobę. W 2003 roku władze rządowe Republiki Włoskiej powierzyły obsługę numeru 114 właśnie Stowarzyszeniu Niebieski Telefon. Pod ten numer należy zawsze dzwonić, gdy jakiekolwiek dziecko w ojczyźnie Dantego znajduje się w niebezpieczeństwie. Pod numer 114 należy także zgłaszać różnego rodzaju nieodpowiednie obrazy, wypowiedzi czy rozmowy rozpowszechniane przez Internet, telewizję, radio czy gazety - które mogą być szkodliwe dla dobra osób nieletnich.

Głównym polem działania organizacji non-profit Niebieski Telefon jest udzielanie różnych form pomocy małoletnim, którzy informują telefonicznie o tym, że doświadczaja przemocy ze strony dorosłych lub innego pogwałcenia swoich praw. Stowarzyszenie przygotowuje także adekwatne modele pracy z dziećmi i młodzieżą dla pracowników socjalnych, pedagogów, nauczycieli itp. W ostatnich latach włoski Niebieski Telefon stał się ważnym punktem odniesienia także dla innych krajów, które podjęły wielkie wyzwanie ochrony praw dzieci i walki z przemocą wobec nieletnich.

W maju 2017 roku, z okazji Narodowego Dnia Walki z Pedofilią, Stowarzyszenie Niebieski Telefon opublikowało własny raport pt. Wykorzystywanie seksualne i pedofilia. Historie, konteksty i nowe wyzwania (por. Telefono Azzurro Onlus 2017). Dokument 
przygotowany przez działaczy tej organizacji non-profit zgłębia zjawisko pedofilii we Włoszech w 2016 roku, odwołując się do najnowszej literatury naukowej włoskiej i zagranicznej. Raport przywołuje także wypowiedzi nieletnich ofiar molestowania seksualnego, prezentując fragmenty zarejestrowanych rozmów telefonicznych, w których ofiary zgłaszały swoje historie działaczom Niebieskiego Telefonu.

Działacze Niebieskiego Telefonu potwierdzają dane Stowarzyszenia Meter i innych organizacji zajmujących się walką z pedofilią, że znakomita większość przypadków molestowania seksualnego dzieci dokonuje się w środowisku rodzinnym oraz w kręgu sąsiadów czy znajomych. Tylko w jednym przypadku na dziesięć sprawca wykorzystania seksualnego nieletnich był kimś zupełnie obcym dla ofiary. Wzrost liczby zgłoszeń przypadków pedofilii, które dotyczą sprawców spoza kręgu osób najbliższych, idzie w parze ze wzrostem liczby takich przestępstw dokonanych w Internecie (uwodzenie, zaczepianie, wabienie, nakłanianie czy „łowienie” dzieci oraz dystrybucja i korzystanie z materiałów pedopornograficznych).

Niestety, Sieć jest przestrzenią, w której bardzo często dzieci wchodzą w relacje potencjalnie ryzykowne z osobami obcymi, nieznanymi, przypadkowymi (por. Web-03). Zdaniem przedstawicieli Niebieskiego Telefonu, Internet i nowe technologie „stały się żyzną glebą, na której zjawisko wykorzystywania seksualnego dzieci znajduje swoje nowe formy wyrazu takie jak sexting, sextortion, grooming oraz live distant child abuse" (Telefono Azzurro Onlus 2017, 11).

Na czym polega sexting? To wysyłanie do innych osób słów, wyrażeń i obrazów o treści jednoznacznie seksualnej. Z omawianego Raportu wynika, że ostatnio to zjawisko gdy chodzi o nieodpowiednie zachowania dorosłych w stosunku do dzieci - rozwija się niezwykle szybko: w 2013 roku przypadki sextingu stanowiły 3,7\% wszystkich zgłoszeń na Telefon Ratunkowy 114, dotyczących wykorzystywania seksualnego dzieci, w 2015 roku już 5,2\%, natomiast w 2016 roku aż
7,1\%. Konsekwencje sextingu mogą być niezwykle poważne z psychologicznego punktu widzenia: negatywny wpływ na samoocenę osoby nieletniej, konsekwencje dotyczące relacji międzyosobowych i opinii o danej osobie, stany lękowe, mniejsze zaangażowanie w zajęcia szkolne itp. W związku z tym, że informacje wprowadzone do Internetu, pozostają tam na zawsze, sexting wobec osób nieletnich może mieć także negatywny wpływ w przyszłości na ich życie osobiste czy zawodowe.

Czym jest sextortion? To forma szantażu o charakterze seksualnym, który polega na możliwości udostępnienia osobom trzecim obrazów ofiary o charakterze seksualnym. Ofiarami tej formy molestowania seksualnego są przede wszystkim dziewczynki. Najczęściej sextortion polega na zamieszczaniu nagich czy intymnych zdjęć bez wyraźnej zgody osób, które te materiały przedstawiaja. Aby nie doszło do rozprzestrzeniania takich zdjęć, ofiara jest zmuszana do relacji seksualnych, do świadczenia różnego rodzaju korzyści finansowych czy materialnych itp. Ofiarami sextortion moga być dzieci lub osoby dorosłe.

Na czym polega grooming? Potocznie poprzez child grooming rozumie się uwodzenie dzieci przez Internet. Grooming w odniesieniu do dzieci można zdefiniować jako działania podejmowane w celu zaprzyjaźnienia się i nawiązania więzi emocjonalnej z dzieckiem, aby zmniejszyć jego opory i później wykorzystać je seksualnie. Jest to także mechanizm używany w tym celu, by nakłonić dziecko do prostytucji czy udziału w wytwarzaniu materiałów pornografii dziecięcej.

Działacze włoskiego Niebieskiego Telefonu wskazują na pięć etapów procesu uwodzenia dzieci przez pedofilów w przestrzeni Internetu (por. Telefono Azzurro Onlus $2017,15-16)$. Na początku takiego przestępstwa jest zawsze stworzenie relacji przyjaźni i wspólnych zainteresowań między pedofilem a wybraną przez niego potencjalną ofiarą. Drugi etap polega na ocenie stopnia prywatności tworzonej relacji, poziomu ryzyka i możliwości odcięcia dziecka od 
kontaktów z innymi osobami, żeby mieć je coraz bardziej tylko dla siebie. Trzeci etap dotyczy stworzenia klimatu intymności i wzajemnego zaufania - w rozmowach sac podejmowane tematy osobiste, przesyła się zdjęcia, mówi się o własnych przeżyciach i uczuciach itp. Następnie pedofil przechodzi do fazy wyłączności: ofiara zaczyna ślepo ufać oprawcy, traci kontakt z najbliższym otoczeniem, fałszywie ocenia pedofila jako osobę opiekuńczą, taktowną i szczerze zainteresowaną jej dobrem. Po przejściu czterech etapów uwodzenia, które mogą zająć kilka miesięcy, pedofil przechodzi do fazy seksualnej - prosi o przesyłanie intymnych zdjęć, rozpoczyna kontakt z wykorzystaniem kamery internetowej, organizuje spotkania offline itp.

Czym jest natomiast live distant child abuse? To nowa forma cyberprzestępczości, która polega na przesyłaniu strumieniowym aktów molestowania seksualnego dzieci. Nowa technologia przesyłania strumieniowego, która bardzo często wykorzystuje platformę Peryskop, umożliwia odtwarzanie danego pliku audio/wideo w tym samym momencie, w którym dane są wysyłane, lub tuż po ich otrzymaniu, by zapobiec przerwom w odtwarzaniu. Przesyłanie strumieniowe eliminuje konieczność pobierania pliku przed jego odtworzeniem. Pliki przesyłane strumieniowo nie są zapisywane na dysku i ich kolejne fragmenty znikają z pamięci tuż po ich odtworzeniu. Live distant child abuse łączy się z turystyką seksualną: $\mathrm{z}$ jednej strony, pedofile oglądający w Internecie akty molestowania seksualnego dzieci są zachęcani przez takie materiały do tego, aby wybrać się osobiście do kraju, z którego materiały pedofilskie były transmitowane, z drugiej - przesyłanie strumieniowe daje możliwość kontynuacji aktywności pedofilskiej po powrocie do własnej ojczyzny z podróży, której celem była turystyka seksualna.

Jakie najważniejsze informacje zawiera prezentowany dokument Niebieskiego Telefonu? Jedno z najważniejszych ustaleń dotyczy rozwoju zjawiska molestowania seksualnego nieletnich: gdy chodzi o przypadki pedofilii zgłaszane do przedstawicieli tej organizacji, w 2016 roku nastąpił wzrost takich przestępstw o 3,4\% w stosunku do 2015 roku. Gdy chodzi o nadużycia seksualne przekazywane pod numer 114, jedna ofiara pedofilii na dwie jest dziewczynką poniżej 11. roku życia. W 2016 roku działacze Niebieskiego Telefonu zajęli się 301 przypadkami pedofilii, które stanowią 7,6\% wszystkich konsultacji telefonicznych. 90\% ofiar pedofilii, zidentyfikowanych przez działaczy tej organizacji non-profit, jest narodowości włoskiej. Znakomita większość aktów wykorzystania seksualnego dzieci dokonuje się w kręgu najbliższych krewnych i znajomych - ponad 90\% przypadków zgłaszanych pod numer 1.96.96 i ponad 80\% przestępstw przekazywanych pod numer 114. Trzy regiony we Włoszech, z których pochodzi najwięcej zgłoszeń dotyczących wykorzystywania seksualnego osób nieletnich to Lombardia (23\% - numer 1.96.96 i 17,8\% - numer 114), Lacjum (12,6\% - numer 1.96.96 i 14,4\% - numer 114) i Wenecja Euganejska (17\% - numer 1.96.96 i 12,7\% - numer 114).

\section{Kościół katolicki i ochrona nieletnich}

Wzrost zainteresowania społeczeństwa włoskiego problemem pedofilii na przestrzeni ostatnich kilkunastu lat łączy się bardzo mocno z wieloma ważnymi inicjatywami, które są podejmowane w tym zakresie przez przedstawicieli Kościoła katolickiego. Jednym z takich ciekawych kościelnych przedsięwzięć była konferencja naukowa, która miała miejsce 23 marca 2017 roku na Papieskim Uniwersytecie Gregoriańskim w Rzymie. Sympozjum zostało zorganizowane przez Papieską Komisję ds. Ochrony Nieletnich oraz Centrum Ochrony Dzieci (Center for Child Protection) Papieskiego Uniwersytetu Gregoriańskiego. Temat konferencji brzmiał następująco: „Ochrona w domu i szkole: ucząc się z doświadczeń całego świata".

Jakie były najważniejsze treści zaprezentowane podczas tej rzymskiej konferencji? O odpowiedzialności i roli edukacji w ważnym dziele ochrony nieletnich przed 
wykorzystaniem seksualnym mówił m.in. Friedrich Bechina, podsekretarz watykańskiej Kongregacji Wychowania Katolickiego. Natomiast Kathleen McCormack, członkini Papieskiej Komisji ds. Ochrony Nieletnich i przewodnicząca grupy roboczej tej Komisji ds. wychowania w rodzinach, w szkołach oraz we wspólnotach, wypowiedziała w trakcie obrad następujące słowa: „Mamy problem wewnątrz Kościoła i wychowanie jest kluczowym narzędziem, aby ten problem zwalczyć. Dążymy do tego, aby wszyscy w swoich wspólnotach i diecezjach - zaangażowali się na rzecz uczynienia Kościoła środowiskiem bezpiecznym dla dzieci" (Traversa 2017).

Bardzo ważną częścią obrad sympozjalnych była prezentacja przykładów dobrych praktyk ochrony nieletnich, realizowanych w różnych krajach świata. Mónica Yerena Suárez z Meksyku mówiła o roli niektórych szkół katolickich $\mathrm{w}$ walce z pedofilią. W tym kraju każdego roku rejestruje się 60o.ooo różnego rodzaju przypadków przemocy seksualnej. Cztery ofiary na dziesięć to dzieci poniżej 15. roku życia. W Meksyku walka z wykorzystywaniem seksualnym dzieci to przede wszystkim wyzwanie kulturowe dotyczące zmiany mentalności społeczeństwa, które ciągle nie traktuje molestowania seksualnego osób nieletnich jako poważnego problemu moralnego czy religijnego. Wilfredo Grajales Rosas z Kolumbii zwrócił uwagę na potrzebę kształtowania u dzieci poczucia własnej wartości jako formy ochrony przez uwodzeniem ze strony pedofilów.

Podczas rzymskiej konferencji Giovanni Ippolito z Włoch mówił o konieczności współpracy między policją i Kościołem katolickim. Juan Ignacio Fuentes z Argentyny zwrócił uwage na konieczność uznania przez Kościół katolicki - w duchu pokory i przejrzystości - własnych błędów popełnionych w przeszłości wobec nieletnich, aby rozpocząć proces rzeczywistej odnowy i prawdziwego pojednania. Francis Sullivan z Australii mówił o pracach Komisji Królewskiej ds. Odpowiedzi Instytucji na Wykorzystywanie Seksualne Dzieci (Royal
Commission into Institutional Responses to Child Sexual Abuse), która od 2013 roku zajmowała się w tym kraju dramatem wykorzystywania seksualnego dzieci. Prelegent z Australii podkreślił, że pedofilia stała się rakiem niszczącym Kościół katolicki. Tylko zdecydowanie usuwając ten nowotwór, z czystymi rękoma, Kościół katolicki może odzyskać utracone zaufanie społeczne (por. Introvigne, Marchesini 2014).

Warto w tym miejscu dodać, że w sierpniu 2017 roku Komisja Królewska przesłała do australijskiego parlamentu 85 propozycji zmian prawnych, mających wzmocnić walkę z podobnymi przestępstwami. Jako jeden z punktów zaproponowano pociąganie do odpowiedzialności karnej księży nieprzekazujących władzom informacji o takich zbrodniach, jeśli nawet usłyszeli o nich podczas sprawowania sakramentu spowiedzi. Ewentualne przyjęcie tej propozycji przez władze w Canberze oznaczałoby zanegowanie tajemnicy spowiedzi w Kościele katolickim w Australii. 14 grudnia 2017 roku Komisja Królewska zakończyła swoją pracę i opublikowała 17 tomów Raportu Końcowego, który prezentuje wstrząsający obraz moralny społeczeństwa australijskiego w ostatnich dziesięcioleciach. Publikacja tego ważnego dokumentu spotkała się z dużym zainteresowaniem opinii publicznej nie tylko w Australii, ale także w wielu innych krajach świata (por. Web-07).

Najważniejszym statutowym celem działania organizatorów rzymskiej konferencji Papieskiej Komisji ds. Ochrony Nieletnich oraz Centrum Ochrony Dzieci - jest wykorzenienie plagi pedofilii z Kościoła, rodzin i społeczeństw oraz wprowadzenie w życie odpowiednich programów ochrony nieletnich przed różnymi formami molestowania seksualnego - dobro ofiar powinno zawsze stać na pierwszym miejscu. W grudniu 2016 roku została uruchomiona w języku angielskim nowa strona internetowa Papieskiej Komisji ds. Ochrony Nieletnich (por. Webo1). Głównym celem tej inicjatywy jest aktualizacja prac podmiotu powołanego przez papieża Franciszka do walki z plagą pedofilii 
oraz promocja różnych programów prewencyjnych, które mogą być wykorzystywane przez kościoły lokalne na wszystkich kontynentach. W 2017 roku strona internetowa została udostępniona także w języku francuskim, hiszpańskim, portugalskim i włoskim.

Warto w tym miejscu podkreślić, że we Włoszech ok. o,o7\% przypadków pedofilii dotyczy osób duchownych. W latach 200o-2016 zostało prawomocnie skazanych w kraju nad Tybrem, z powodu molestowania seksualnego dzieci, 117 księży lub zakonników. Na przestrzeni ostatnich kilkunastu lat włoskie media informowały o niezwykle bulwersujących przypadkach pedofilii, które przyczyniły się do osłabienia wiarygodności Kościoła katolickiego w tym kraju (por. Angilletti 2016; Moretti 2016). Na początku 2017 roku ukazała się książka dziennikarza śledczego Emiliana Fittipaldiego pt. Pożadanie: Grzechy, skandale i zdrady Kościoła, który składa się z ludzi. Autor tego opracowania opisał historie 200 duchownych oskarżonych o pedofilię. Jaka jest realna skala pedofilii w Kościele katolickim we Włoszech? Trudno powiedzieć. W Italii nie ma wiarygodnych raportów podobnych to tych, które w ostatnich latach przygotowano w USA, Australii czy Irlandii (por. Kobyliński 2016a; Kobyliński 2016b). Nie ma też ogólnokrajowego planu odszkodowań finansowych dla ofiar. W niektórych diecezjach doszło jedynie do długich procesów sądowych, w których ofiary molestowania seksualnego domagały się zadośćuczynienia finansowego.

Włoski socjolog Massimo Introvigne twierdzi, że główną przyczyną rozwoju zjawiska pedofilii w Kościele katolickim było permisywne podejście do moralności, które po rewolucji seksualnej 1968 roku zaczęło przenikać do kręgów katolickich w większości krajów zachodnich (por. Web-02). Np. w Belgii idee tej rewolucji zdominowały nie tylko życie społeczne tego kraju, ale przeniknęły także bardzo głęboko do środowisk katolickich. Dzisiaj trudno w to uwierzyć, ale w Belgii czy Holandii w latach 70. i 80. ubiegłego wieku różne formy pedofilii były promowane nawet przez niektóre organizacje katolickie (por. Kobyliński 2017a).

Wydaje się, że na rozwój zjawiska wykorzystywania seksualnego dzieci w społeczeństwie włoskim miała bardzo duży wpływ „omertà", czyli zmowa milczenia. Od wielu lat o „kulturze milczenia” (cultura del silenzio) mówi bardzo często maltański arcybiskup Charles Scicluna, który w latach 2002-2012, jako Promotor Sprawiedliwości w Kongregacji Nauki Wiary, był prawą ręką kardynała Josepha Ratzingera w walce z plaga pedofilii. „Omertà” i „kultura milczenia” oznaczają klimat przyzwolenia na molestowanie seksualne dzieci, który dotyczy ofiar, rodzin, instytucji, kościołów i środków masowej komunikacji.

Gdy na początku 2016 roku Amerykańska Akademia Filmowa uznała „Spotlight” Toma McCarthy'ego za najlepszy film 2015 roku (por. Carroll, Cullen 2016), Scicluna stwierdził w wywiadzie dla włoskiego dziennika „La Repubblica”, że film „Spotlight” powinni zobaczyć „wszyscy kardynałowie i biskupi, ponieważ muszą zrozumieć, że Kościół uratuje zgłaszanie przypadków pedofilii, a nie «omertà», czyli zmowa milczenia. Słowo kluczowe tego filmu to właśnie «omertà». «Spotlight» pokazuje, że obrona nade wszystko dobrego imienia Kościoła okazała się całkowicie błędna. Przełomu w walce z pedofilią dokonał Joseph Ratzinger jako prefekt Kongregacji Nauki Wiary i później jako papież" (Kobyliński 2016c).

\section{Deklaracja Rzymska 2017}

W dniach od 3 do 6 października 2017 roku miało miejsce w Rzymie wydarzenie bez precedensu, gdy chodzi o wszelkie znane dotychczas formy walki z pedofilią na przestrzeni dziejów. Tej dramatycznej pladze moralnej, po raz pierwszy w historii, został poświęcony kongres naukowy o charakterze globalnym pt. „Godność dziecka w świecie digitalnym" (Child Dignity in the Digital World). Konferencja została zorganizowana przez Centrum Ochrony Dzieci Papieskiego Uniwersytetu Gregoriańskiego (por. Web-05). 
W spotkaniu wzięło udział 150 uczestników ze wszystkich kontynentów, m.in. przedstawiciele największych na świecie przedsiębiorstw z branży technologii informacyjnych (Microsoft, Facebook, Google), naukowcy, eksperci, działacze organizacji pozarządowych, politycy, funkcjonariusze organów ścigania, pracownicy służb porządkowych i wymiaru sprawiedliwości, przedstawiciele różnych religii. Wśród uczestników kongresu było także wielu ważnych przedstawicieli Stolicy Apostolskiej, w tym Sekretarz Stanu kard. Pietro Parolin, oraz reprezentanci najwyższych władz Republiki Włoskiej, m.in. marszałek Senatu Pietro Grasso i minister edukacji Valeria Fedeli.

Głównym celem spotkania było stworzenie platformy dyskusji oraz wypracowanie serii konkretnych inicjatyw, służących walce z pedofilią w świecie cyfrowym oraz promujących ochronę osób nieletnich przed molestowaniem seksualnym w Internecie. Dzieci i osoby nieletnie stanowią obecnie jedną czwartą użytkowników globalnej Sieci, których liczba w 2017 roku przekroczyła 3,2 miliarda. Wszystko wskazuje na to, że w niedalekiej przyszłości wszyscy mieszkańcy ziemi będą mieć dostęp do technologii digitalnych - w ten sposób cała ludzkość zamieszka w jednej globalnej wiosce cyfrowej. Tylko w Indiach w latach 2018-2019 uzyska dostęp do Internetu ponad 500 milionów mieszkańców, z których połowę będą stanowić osoby nieletnie. Już dzisiaj ponad 800 milionów dzieci na wszystkich kontynentach jest narażonych na ryzyko związane z różnymi formami molestowania seksualnego w świecie cyfrowym. W najbliższych latach wszystkie dzieci świata będą żyć w globalnej wiosce digitalnej i w konsekwencji staną się potencjalnymi ofiarami nowych form pedofilii online.

Jakie tematy zdominowały obrady kongresu na Papieskim Uniwersytecie Gregoriańskim? Kilkudziesięciu prelegentów przedstawiło m.in. aktualne dane dotyczace zjawiska wykorzystywania seksualnego dzieci oraz konsekwencje rozwoju nowych technologii informacyjnych, które są wykorzystywane przez współczesnych pedofilów. W trakcie konferencji poddano także kompleksowej analizie wpływ zjawiska pornografii dziecięcej na psychikę osób nieletnich. Niektórzy mówcy przedstawili w swoich wystąpieniach różne profile osobowościowe pedofilów. Wydaje się, że najważniejszym przesłaniem większości wypowiedzi było poszukiwanie adekwatnych rozwiązań wielkiego wyzwania moralnego, jakim stała się dzisiaj pedofilia. W trakcie kongresu wielu mówców stwierdziło jednoznacznie, że $\mathrm{w}$ walce $\mathrm{z}$ tą straszną plagą potrzeba odpowiednich inicjatyw politycznych, nowych przepisów prawnych o charakterze narodowym i międzynarodowym, większego zaangażowania mediów i firm z branży technologii informacyjnych, bardziej stanowczej postawy przedstawicieli religii, kościołów i związków wyznaniowych.

W jaki sposób przebiegały obrady rzymskiej konferencji? Poranne sesje plenarne były transmitowane na żywo na kanale You Tube, natomiast spotkania popołudniowe w grupach warsztatowych odbywały się przy drzwiach zamkniętych. Jednym z ważnych mówców był prof. Hans Zollner - niemiecki jezuita, który jest prezesem Centrum Ochrony Dzieci Papieskiego Uniwersytetu Gregoriańskiego. Prelegent przypomniał, że wykorzystywanie seksualne dzieci istnieje we wszystkich społeczeństwach, kulturach i krajach świata. To zło jest o wiele bardziej rozprzestrzenione niż może się wydawać. W krajach Unii Europejskiej co piąte dziecko doświadcza różnych form molestowania seksualnego. Niestety, nie mamy dokładnych danych dotyczacych innych kontynentów. Dlatego nie wiemy, jaka jest realna skala pedofilii w Azji, w Afryce czy w Ameryce Południowej.

Pierwszego dnia obrad, prezentując program całego kongresu, prof. Ernesto Caffo - założyciel włoskiego Stowarzyszenia Niebieski Telefon - stwierdził, że statystyki dotyczące wykorzystywania seksualnego dzieci są niepewne, ponieważ znakomita większość takich przestępstw nie 
jest zgłaszana organom ścigania. Należy przypuszczać, że w 2013 roku tylko w krajach Unii Europejskiej aż 18 milionów osób nieletnich doświadczyło różnych form molestowania seksualnego. Niektóre badania pokazują, że ofiarami tej nowej plagi globalnej jest od $7 \%$ do $36 \%$ dziewczynek i od 3\% do $29 \%$ chłopców. Z badań prowadzonych przez Internet Watch Foundation wynika, że 60\% materiałów pedopornograficznych, dostępnych w Sieci, jest wykorzystywanych przez Internautów z krajów europejskich. W 2016 roku tylko funkcjonariuszom Interpolu udało się zidentyfikować 57 tys. przypadków wykorzystania seksualnego dzieci w świecie cyfrowym (zdjęcia nagich dzieci, filmy pornograficzne $z$ udziałem osób nieletnich itp.). Z danych Interpolu wynika, że w 2016 roku każdego dnia pięcioro dzieci było wykorzystanych do produkcji materiałów pedopornograficznych. W niektórych przypadkach do filmowania gwałtu zostały wykorzystane dzieci w wielu 3-4 lat.

Ciekawy referat na rzymskiej konferencji wygłosiła m.in. prof. Mary Ann Layden z Uniwersytetu Pensylwanii w USA, która skoncentrowała swoją uwagę na wpływie różnych rodzajów pornografii na osobowość dzieci i osób dorosłych. Gdy dziecko ma kontakt z obrazami pornograficznymi, jego świat wyobraźni wypełnia się treściami i uczuciami, których nie może adekwatnie ocenić, ponieważ jego mózg nie jest jeszcze do tego przygotowany. Neurobiologia, psychologia i psychiatria jednoznacznie potwierdzają, że obrazy przedstawiające przemoc i seks mają głęboki wpływ na plastyczne umysły dzieci. Z tego powodu rodzi się wiele zaburzeń w rozwoju emocjonalnym i osobowościowym. Bardzo często te zaburzenia będą miały wpływ na całe życie dzisiejszych dzieci. Jednym z najbardziej negatywnych wymiarów pedofilii online jest fakt, że obrazy raz wprowadzone do świata digitalnego, pozostaną w nim w jakimś sensie na zawsze. W tym kontekście można mówić o nieodwracalnych skutkach materiałów pornograficznych na dzieci i osoby dorosłe.
Z kolei prof. Donald Hilton z Centrum Nauk o Zdrowiu Uniwersytetu Teksańskiego w Stanach Zjednoczonych mówił o wpływie pornografii na funkcjonowanie mózgu osób nieletnich. Mówca podkreślił, że w ostatnich latach przesuwa się coraz bardziej granica początku okresu dojrzewania. Obecnie w społeczeństwie amerykańskim dziewczynki kończą własny rozwój seksualny w wieku 13-14 lat, a okres dojrzewania w sensie fizjologicznym rozpoczyna się już w wieku 9-10 lat. Z jednej strony, obniża się coraz bardziej wiek menarchy, z drugiej rozwój mózgu pozostaje na wcześniejszym poziomie, a nawet jest coraz bardziej opóźniony. Niestety, bardzo wczesnej dojrzałości ciała nie odpowiada dojrzałość osobowościowa czy poznawcza. Dzieciom brakuje także pogłębionej świadomości własnej tożsamości seksualnej. W konsekwencji osoby nieletnie w bardzo młodym wieku podejmują zachowania seksualne, ale de facto nie zdają sobie sprawy z tego, co czynią. Dlatego istnieje dzisiaj pilna potrzeba, aby w ramach edukacji domowej i szkolnej kształtować u dzieci większą integrację między sferą biologiczną a zasadami etycznymi.

Kolejna mówczyni ze Stanów Zjednoczonych, prof. Elizabeth Letourneau z Uniwersytetu Johna Hopkinsa w Baltimore, zwróciła uwagę w swoim wystąpieniu na różne formy zapobiegania wykorzystywaniu seksualnemu dzieci. Globalna plaga pedofilii nie jest żadną nieuleczalną chorobą, której nie możemy leczyć. Wprost przeciwnie - ciąży na nas moralny obowiązek zapobiegania temu zjawisku, prewencji i ochrony nieletnich. W tym celu potrzeba odpowiednich przepisów o charakterze narodowym i międzynarodowym. Pedofile powinni mieć przede wszystkim świadomość nieuchronności wysokich kar za krzywdy wyrządzone niewinnym dzieciom. Potrzeba także stabilizacji życia rodzinnego i odpowiedniej profilaktyki. Działania profilaktyczne powinny obejmować różne grupy społeczne, a zwłaszcza nauczycieli, którzy często nie posiadają wystarczającej wiedzy na temat realnych problemów dzieci i nastolatków, 
mających łatwy i często niekontrolowany dostęp do Internetu.

6 października 2017 roku wszyscy uczestnicy kongresu, podejmującego problem pedofilii w świecie cyfrowym, zostali przyjęci przez papieża Franciszka na specjalnej audiencji w Sali Klementyńskiej Pałacu Apostolskiego w Watykanie. To spotkanie potwierdziło zdecydowaną postawę Kościoła katolickiego w walce z plagą wykorzystywania seksualnego dzieci. Papież Franciszek stwierdził w swoim wystąpieniu, że nie wolno lekceważyć skali tego dramatu. Ten nowy i niezwykle poważny problem o charakterze globalnym wymaga odpowiednich regulacji prawnych. Papież przyznał, że w przeszłości także Kościół katolicki nie zatroszczył się odpowiednio o ochronę nieletnich. W obliczu wielkich wyzwań nie wolno się poddawać, przeciwnie - należy z odwagą, pasją i determinacją stawać w obronie dzieci.

Papież Franciszek podkreślił, że żyjemy dzisiaj w zupełnie nowym świecie, który jest nazywany światem cyfrowym bądź światem digitalnym (digital world). Ta zupełnie nowa rzeczywistość jest owocem niezwykłego rozwoju nauki i techniki, który na przestrzeni kilku ostatnich dziesięcioleci zmienił bardzo głęboko nasz sposób komunikowania się i życia. Zmianie uległ także nasz sposób myślenia, wpływając na postrzeganie naszych możliwości i naszej tożsamości. Z jednej strony, jesteśmy zafascynowani niezwykłymi możliwościami, jakie daje nam współczesny rozwój technologiczny, z drugiej - budzi się w nas lęk, gdy chodzi o negatywne konsekwencje obecnej rewolucji naukowo-technicznej. Zasadnicze pytania brzmią następująco: Czy jesteśmy w stanie kierować procesami, które sami wprowadziliśmy w ruch? Czy te procesy nie wypadły nam z rąk? Czy robimy wszystko, co możliwe, aby je odpowiednio kontrolować?

Na zakończenie audiencji uczestnicy kongresu wręczyli papieżowi przygotowany wspólnie dokument, nazwany Deklaracją Rzymską (Dichiarazione di Roma). Deklaracja, składająca się z trzynastu punktów, została podpisana przez wszystkich uczestników tej jakże ważnej konferencji naukowej. W dokumencie potwierdzono zaangażowanie sygnatariuszy na rzecz ochrony nieletnich i wystosowano apel do władz politycznych, religijnych, technologicznych i samorządowych, aby zostały podjęte szybkie i skuteczne działania w walce ze strasznymi przestępstwami seksualnymi, których ofiarami są niewinne dzieci.

„Życie każdego dziecka - stwierdzają sygnatariusze Deklaracji - jest wyjątkowe, ważne i cenne. Każde dziecko ma prawo do godności i bezpieczeństwa. Jednakże dzisiaj społeczeństwo globalne poważnie zaniedbuje swój obowiązek ochrony dzieci. W całym świecie miliony osób nieletnich są wykorzystywane w sposób tragiczny i trudny do opisania, na skalę nigdy dotąd nieznaną" (Web-o6). Choć nie ma wątpliwości, że Internet sprawia wiele korzyści i daje wiele możliwości w zakresie integracji społecznej i edukacji, to nie wolno zapominać o tym, że obecnie coraz bardziej ekstremalne i odczłowieczające treści w świecie cyfrowym są dosłownie na wyciągnięcie ręki małych dzieci.

Niestety, rozprzestrzenianie się mediów społecznościowych - oprócz wielu aspektów pozytywnych - oznacza także to, że stają się coraz częstsze takie działania, jak cyberprześladowanie, nękanie czy sextortion. Ogromna liczba obrazów wykorzystywania seksualnego dzieci i młodzieży jest dostępna online i rośnie bez ograniczeń. Dlatego sygnatariusze Deklaracji Rzymskiej apelują m.in. do liderów z branży technologii informacyjnych, aby zaangażowali się w opracowywanie i wdrażanie nowych narzędzi i technologii, w celu przeciwdziałania rozprzestrzenianiu się obrazów wykorzystywania seksualnego nieletnich $\mathrm{w}$ Internecie i zapobieganiu redystrybucji takich materiałów w globalnej wiosce cyfrowej.

Zdaniem uczestników rzymskiego kongresu, w dobie gwałtownego rozwoju technologii digitalnych świat stoi przed niespotykanymi dotąd wyzwaniami, dotyczącymi ochrony praw i godności dzieci. Wyzwania te wymagają nowego sposobu myślenia, nowej globalnej świadomości 
i nowych form przywództwa moralnego i politycznego. To problem, którego nie mogą rozwiązać poszczególne narody, biznes lub religie. Dlaczego? Ponieważ mamy do czynienia z problemem planetranym, który wymaga globalnych rozwiązań i zaangażowania wszystkich rządów, instytucji, religii i firm z branży technologii informacyjnych.

\section{Podsumowanie}

W ostatnich latach rozwija się niezwykle szybko w wymiarze globalnym dramatyczna plaga pedofilii, która stała się nową formą niewolnictwa. Z jednej strony, w wielu krajach są podejmowane różne inicjatywy społeczne, których głównym celem jest walka z wykorzystywaniem seksualnym osób nieletnich, z drugiej - Internet i nowoczesne technologie informatyczne dają radykalnie nowe możliwości pedofilom, gdy chodzi o kontakt z dziećmi w świecie wirtualnym czy dystrybucję materiałów pedopornograficznych.

Przede wszystkim należy budzić adekwatną świadomość moralną dotyczącą zupełnie nowych wyzwań, gdy chodzi o wykorzystywanie seksualne dzieci w świecie cyfrowym. Potrzeba większej kontroli politycznej i społecznej nad rozwojem najnowszych technologii, które umożliwiają nowe formy pedofilii. W naszej epoce historycznej konieczne stały się szeroko zakrojone badania interdyscyplinarne, prowadzone w różnych obszarach nauki i wiedzy, powiązanych ze zjawiskiem wykorzystywania seksualnego dzieci.

Już dzisiaj ponad 800 milionów nieletnich jest narażonych na ryzyko związane z różnymi formami molestowania seksualnego w świecie cyfrowym. W najbliższych latach wszystkie dzieci świata będą żyć w globalnej wiosce digitalnej i w konsekwencji staną się potencjalnymi ofiarami nowych form pedofilii on line. Jednym z wielu państw, w których pedofilia stała się ostatnio przedmiotem żywego zainteresowania opinii publicznej, są m.in. Włochy. Analiza zjawiska molestowania seksualnego dzieci w tym kraju prowadzi do siedmiu następujących wniosków.

Po pierwsze, globalna plaga pedofilii wymaga szeroko zakrojonych działań w wymiarze międzynarodowym. W dobie Internetu i globalizacji nie można skutecznie rozwiązać tego problemu w jednym kraju, jeśli w innych państwach będzie przyzwolenie dla relacji seksualnych między osobami dorosłymi i dziećmi. Potrzeba działań o charakterze międzynarodowym i interdyscyplinarnym, ponieważ nikt sam nie jest w stanie rozwiązać problemu pedofilii: ani rządy państw, ani policja, ani religie czy nauczyciele i wychowawcy. Potrzeba wielu inicjatyw zespołowych, żeby skutecznie zwalczyć tę straszną plagę. Problem o charakterze globalnym wymaga działań zaradczych o charakterze globalnym.

Pedofilom dość często sprzyja korzystny dla nich klimat społeczny, w którym ludzkie ciało staje się towarem, a pedofilia jest traktowana jako jedna ze skłonności seksualnych (por. Web-04). W tym kontekście trudno pogodzić się z obojętnością świata np. wobec dramatu małych dziewczynek, wydawanych przymusowo za mąż w Indiach, Afganistanie, Jemenie czy Somalii. Każdego roku zmusza się do takich małżeństw 15 milionów nieletnich dziewcząt, z których najmłodsze mają 10 lat. Niestety, przy takiej mentalności światowej opinii publicznej, będziemy w przyszłości obserwować najprawdopodobniej dalszy wzrost dramatu seksualnego wykorzystywania osób nieletnich.

Trudno także zrozumieć milczenie świata w stosunku do Turcji, która w 2016 roku wprowadziła niekaralność relacji seksualnych osób dorosłych z dziećmi powyżej 12 . roku życia. Władze w Ankarze zdecydowały, że relacje seksualne osoby dorosłej z dzieckiem, które ukończyło 12 lat są zgodne z obowiązującym prawem - w takim przypadku koniecznym warunkiem niekaralności jest zgoda dziecka na taką relację. Ewentualne skargi wykorzystanych seksualnie dzieci są rozpatrywane tak samo, jak przypadki molestowania seksualnego osób dorosłych. 
W kontekście ostatnich zmian, dokonanych w Turcji, niezwykle poważnym problemem jest nauczanie Koranu dotyczące relacji seksualnych między osobami dorosłymi i dziećmi. Nie można walczyć skutecznie z pedofilią, jeśli w wielu krajach świata istnieje przyzwolenie polityczne, prawne, religijne i społeczne na relacje seksualne między osobami dorosłymi i nieletnimi. Dlatego potrzeba przede wszystkim budzenia świadomości moralnej i wielu nowych opracowań antropologicznych, etycznych czy psychologicznych, które pomogą lepiej rozumieć przyczyny skłonności pedofilskich oraz konsekwencje psychiczne, z którymi muszą zmierzyć się ofiary takich przestępstw.

Po drugie, na ogólnoświatowej mapie pedofilii specyfiką Włoch nie jest liczba przypadków wykorzystywania seksualnego osób nieletnich, ale mentalność i swego rodzaju „kultura milczenia”, która dopiero w ostatnich latach jest zastępowana przez otwartą debatę publiczną na temat dramatu molestowania seksualnego dzieci. W kraju nad Tybrem rejestruje się każdego roku ok. 21.000 przypadków pedofilii. Jest to wielkość zbliżona do innych państw zachodnich, procentowo trochę niższa od liczby przypadków wykorzystywania seksualnego nieletnich zgłaszanych we Francji czy Wielkiej Brytanii. W przeszłości we Włoszech najbardziej zdumiewała kultura milczenia i ukrywanie pedofilii. Dlatego realny obraz problemu może być gorszy od tego prezentowanego w różnego rodzaju raportach.

Warto w tym miejscu dodać, że jednym z elementów specyficznych dla plagi pedofilii w społeczeństwie włoskim jest niewątpliwie tzw. turystyka seksualna. Mekką dla włoskich pedofilów jest m.in. Dominikana, która jest znana w całym świecie z szerokiej skali pedofilii homoseksualnej. „Każdego roku 80.0oo mieszkańców Włoch wybiera za cel podróży kraje tzw. turystyki seksualnej. Niestety, agencje turystyczne nie składają żadnych zawiadomień do organów ścigania [...]. Panuje niewiarygodna omertà. Włoskie prawo przewiduje kary dla tych, którzy udają się za granicę, aby wykorzystywać seksualnie osoby nieletnie. Ale od 20 lat, odkąd istnieje to prawo, ile postępowań wszczęto? Tylko jedno, dokładnie 20 lat temu" (Web-o8).

Po trzecie, potrzeba ciągle budzenia świadomości moralnej, jak wielkim złem jest wykorzystywanie seksualne dzieci. W tym kontekście niezwykle aktualne są słowa Fortunata Di Noto, włoskiego duchownego katolickiego, zaangażowanego od wielu lat $\mathrm{w}$ walkę z pedofilią, który twierdzi w swoich publikacjach, że mamy dzisiaj do czynienia z prawdziwym handlem ciałami niewinnych dzieci. Na naszych oczach dokonuje się "cichy holokaust”, który potrzebuje głosu proroków - odważnych kobiet i mężczyzn - aby przeciwstawić się obojętności i tuszowaniu zła. Di Noto twierdzi, że przede wszystkim trzeba zerwać zmowę milczenia. Należy walczyć o to, aby pedofilia została uznana za zbrodnię przeciwko ludzkości, prawdziwe pedobójstwo. Te bardzo mocne słowa włoskiego księdza zwracają uwagę na wielki dramat niewinnych dzieci, krzywdzonych przez pedofilów. Z raportów włoskiego Stowarzyszenia Meter jasno wynika, że w 99.9\% przypadków działania pedofilów są świadome i dobrowolne, dlatego powinny podlegać procedurze karnej.

Warto podkreślić, że 22 listopada 2017 roku w ambasadzie naszego kraju przy Stolicy Apostolskiej podpisano umowę między polską Komendą Główną Policji a Stowarzyszeniem Meter. Dzięki temu polskie organa ścigania będą mieć dostęp do różnego rodzaju informacji dotyczących pedofilii, uzyskanych przez działaczy włoskiej organizacji. Komentując podpisanie umowy dla Radia Watykańskiego, Fortunato Di Noto stwierdził, że Stowarzyszenie Meter wielokrotnie podejmowało starania, aby o przestępczej działalności pedofilów informować policję zainteresowanych krajów. Zawsze jednak pojawiały się bariery biurokratyczne. Porozumienie z polską policją umożliwia kontakt bezpośredni i jest wzorem dla innych krajów.

Po czwarte, wielkim wyzwaniem jest obecnie pedofilia kulturowa, która oznacza różne sposoby promocji zachowań pedofilskich w kulturze masowej. Internet służy nie tylko 
do dystrybucji filmów czy zdjęć pornografii dziecięcej, ale jest wykorzystywany także do promocji zachowań pedofilskich jako rzekomo jednej z wielu orientacji seksualnych człowieka. W wielu krajach niezwykle wpływowe i dobrze zorganizowane środowiska dążą do swego rodzaju normalizacji pedofilii. W Internecie istnieje bardzo dużo grup pedofilskich, w których opowiada się własne historie kontaktów seksualnych z dziećmi lub przeprowadza testy, dzięki którym można „zmierzyć” poziom zainteresowania seksualnego osoby dorosłej w stosunku do małoletnich.

Po piąte, zjawisko wykorzystywania seksualnego dzieci wymaga dalszych szeroko zakrojonych badań interdyscyplinarnych. Jedną z ważnych kwestii teoretycznych jest właściwe odróżnienie czynów pedofilnych od pedofilii. Są to pojęcia bliskoznaczne, ale nie równoznaczne. Jakie kryteria należy przyjąć, aby właściwie odróżnić jedne zachowania od drugich? Czym powinna się różnić ocena etyczna poszczególnych rodzajów wykorzystywania seksualnego osób nieletnich? W jakich okolicznościach czyny pedofilne nie przesądzają o rozpoznaniu pedofilii?

Czynami pedofilnymi są wszystkie zachowania osób dorosłych wobec dzieci, które są motywowane seksualnie, służą wzbudzeniu podniecenia seksualnego i zaspokajaniu popędu sprawców tego rodzaju zachowań. Takich czynów mogą dokonywać niekoniecznie pedofile, a więc osoby, u których stwierdza się dewiację seksualną. Mogą ich dokonywać także inne osoby, które w różnorodnych okolicznościach - pod wpływem różnorakich czynników - podejmują zachowania seksualne służące zaspokojeniu własnego popędu poprzez kontakt z dzieckiem lub na skutek obcowania z materiałami erotycznymi prezentującymi seksualność dziecka.

Dlatego jest zawsze konieczna pogłębiona analiza różnych form molestowania seksualnego dzieci, aby rzetelnie ustalić, czy mamy do czynienia z zachowaniem motywowanym pedofilią jako jedną $\mathrm{z}$ wielu dewiacji seksualnych, czy też z tzw. motywacją zastępczą. W zastępczych czynach pedofilnych dorosły człowiek realizuje swój popęd seksualny z dzieckiem wyłącznie z konieczności, ponieważ z różnych powodów ma utrudniony lub uniemożliwiony kontakt seksualny z dorosłym partnerem. W takich przypadkach dzieci stanowią jedynie substytut osób dorosłych. Właściwe odróżnienie czynów pedofilnych od pedofilii ma pewne znaczenie dla zrozumienia motywacji sprawców takich zachowań oraz dla określenia adekwatnych form ochrony osób nieletnich.

Po szóste, w wielu krajach świata - szczególnie w państwach Azji, Afryki i Ameryki Południowej - potrzeba wielkiego wysiłku społecznego, żeby zerwać zasłonę milczenia wokół pedofilii (por. Luparia 2017; Monzani, Bandiera 2017; Muzzana 2017). Przykład Włoch wyraźnie pokazuje, że budzenie świadomości publicznej wobec molestowania seksualnego dzieci wymaga czasu: $w$ tym kraju dopiero od niedawna namysł nad pedofilia jest obecny w domenie publicznej, natomiast wcześniej pozostawał tematem tabu. „Kultury milczenia” doświadczyłem osobiście w kraju nad Tybrem na początku lat 90. ubiegłego wieku. W tym okresie mogłem swobodnie rozmawiać o dramacie pedofilii w niektórych środowiskach w Niemczech czy Wielkiej Brytanii, natomiast podejmowanie tego tematu we Włoszech było wówczas niezwykle trudne, praktycznie niemożliwe. Gdy chodzi o walkę z pedofilią w kraju nad Tybrem, powstaje tam obecnie wiele różnych organizacji, fundacji i stowarzyszeń, których celem jest ochrona nieletnich przed przemocą psychiczną czy seksualną. Wielu autorów stwierdza stanowczo, że we Włoszech jest dzisiaj potrzebny narodowy plan walki z pedofilią.

Warto w tym miejscu podkreślić, że funkcjonowanie zmowy milczenia wokół pedofilii w naszych polskich warunkach zostało doskonale opisane w książce Marcina Kąckiego Maestro, która ukazała się w 2013 roku. To reporterska historia wielkiego skandalu pedofilskiego w chórze Polskie Słowiki oraz jego dyrygenta Wojciecha Kroloppa. Kącki 
odsłania w swojej książce wielowymiarowy układ zależności, powiązań towarzyskich, uwikłań, kłamstw i interesów, który sprawił, że przez 40 lat wykorzystywanie seksualne małych chłopców w chórze Polskie Słowiki było tematem tabu dla tysięcy osób, które miały szeroką wiedzę na temat tego wstrząsającego dramatu moralnego.

Po siódme, adekwatnych działań o charakterze międzynarodowym wymaga rozwijająca się plaga pedofilii w przestrzeni Darknet. W 2013 roku Unia Europejska powołała do istnienia Europejskie Centrum ds. Walki z Cyberprzestępczością (European Cybercrime Centre), będące częścią Europolu i mieszczące się w Holandii. Cyberprzestępczość odnosi się do przestępstw popełnianych z użyciem komputerów i sieci komunikacyjnych (np. Internetu). Charakter cyberprzestępczości sprawia, że nie napotyka ona żadnych granic. To nowe wyzwanie wymaga koordynacji i współpracy pomiędzy organami ścigania różnych państw. Jedną $\mathrm{z}$ istotnych form cyberprzestępczości jest wykorzystywanie seksualne osób nieletnich.

W ostatnich latach Europejskie Centrum ds. Walki z Cyberprzestępczością odegrało niezwykle ważną rolę w rozbiciu kilku międzynarodowych grup pedofilów, działających najczęściej w przestrzeni Darknet, do których należeli także obywatele Włoch. Potrzeba dzisiaj spójnych i jednolitych regulacji prawnych na poziomie międzynarodowym. Istnieje ciągle poważna luka między społeczeństwem obywatelskim, które zamierza skutecznie walczyć z tymi przestępstwami, a niezdolnością legislacyjną wspólnoty międzynarodowej, żeby w odpowiedni sposób zbierać dane dotyczące pedofilii, wymieniać je między zainteresowanymi państwami i prowadzić adekwatne czynności procesowe.

\section{Bibliografia}

Angilletti M., 2016, Morbi et Orbi. Pedofilia, omosessualità e fede nella Chiesa di oggi, Falco Editore, Cosenza.

Associazione Meter Onlus, 2017, Report annuale 2016. Pedofilia e pedopornografia. Un crimine contro $i$ bambini, Meter Onlus sede nazionale, Avola.
Barbagli M., Dalla Zuanna G., Garelli F., 2010, La sessualità degli italiani, Il Mulino, Bologna.

Bellaspiga L., 2015a, Sweetie, la bimba esca che svergogna il mondo, Avvenire, nr 308, I.

Bellaspiga L., 2015b, Bambini straziati, nulla di virtuale, Avvenire, nr 308, II.

Bellaspiga L., 2017, Pedofilia, incubo mundiale, Avvenire, $\mathrm{nr} 67,13$.

Buono G., De Luca R., 2015, La pedofilia in Internet: Come proteggere i nostri figli dai pericoli del Web, Greenbooks Editore, Roma.

Carroll M., Cullen K. i in., 2016, Zdrada. Spotlight. Kryzys w Kościele katolickim, HarperCollins Polska, Warszawa.

DeMause L., 1998, The History of Child Abuse, The Journal of Psychohistory, nr 25/3, 216-236.

Di Gregorio L., 2016, La voglia oscura. Pedofilia e abuso sessuale, Giunti Editore, Firenze.

Di Noto F., 2002, La pedofilia. I mille volti di un olocausto silenzioso, Paoline Editoriale Libri, Milano.

Felix I., 2016, Quando stupro e pedofilia sono favoriti dai genitori, FACS Edizioni, Sant'Egidio alla Vibrata.

Frassi M., 2011, Il libro nero della pedofilia, Editore La Zisa, Palermo.

Guenzi P.D., 2004, Pedofilia, in: Nuovo Dizionario di Bioetica, red. S. Leone, S. Privitera, Città Nuova Editrice - Edizioni ISB dell'Istituto Siciliano di Bioetica, Roma - Arcireale, 843-852.

Introvigne M., Marchesini R., 2014, Pedofilia. Una battaglia che la Chiesa sta vincendo, Sugarco Edizioni, Milano.

Kącki M., 2013, Maestro. Historia milczenia, Wydawnictwo Agora SA, Warszawa.

Kershnar St., 2017, Pedophilia and Adult-Child Sex: A Philosophical Analysis, Lexington Books, Lanham.

Kobyliński A., 2016a, Il dramma degli abusi sessuali sui minori nella Chiesa cattolica d'Irlanda, Studia Bobolanum, nr 27/4, 123-137.

Kobyliński A., 2016b, Problem molestowania seksualnego dzieci w Australii, Studia Ecologiae et Bioethicae, nr 14/2, 57-75.

Kobyliński A., 2016c, Pedofilia i zmowa milczenia, Do Rzeczy, nr 12, 6.

Kobyliński A., 2017a, Pedofilia w Belgii: rewolucja seksualna, sekularyzacja i nowa moralność, Studia Bobolanum, nr 28/1, 219-236. 
Kobyliński A., 2017b, Skandal i zło pedofilii, wSieci, nr 11, 44-46.

Kramer S., 2017, Female-Perpetrated Sex Abuse: Knowledge, Power, and the Cultural Conditions of Victimhood, Routledge - Taylor \& Francis Group, Abingdon.

Luparia M.E., 2017, Prevenire la pedofilia cominciando da noi, Lateran University Press, Roma.

McNamara D., 2016, Child Sexual Abuse: Never Call It Love, Celtic Balm Publishers, Olympia.

Monzani M., Bandiera V., 2017, Pedofilia e pericolosità sociale. La psicologia di oggi e il diritto penale di ieri: nuove proposte legislative, Edizioni Libreriauniversitaria.it, Limena.

Moretti A., 2016, Voglia di caramelle. Storie vere dalle nebbie della pedofilia sociale e religiosa, Iemme Edizioni, Napoli.

Muzzana T., 2017, La predazione. Manuale di prevenzione alla pedofilia e al bullismo, Edizioni Tecnografica, Lomazzo.

Pinotti F., 2008, Olocausto bianco, BUR Biblioteca Universale Rizzoli, Milano.

Sero M.C., 2007, Pedophilia and Sexual Offending Against Children: Theory, Assessment, and Intervention, American Psychological Association, Washington DC.

Telefono Azzurro Onlus, 2017, Abuso sessuale e pedofilia. Storie, contesti e nuove sfide, Presidenza del Consiglio dei Ministri, Roma.

Traversa G. P., 2017, Abusi sui minori, prima di tutto tutelare le vittime, Avvenire, nr 70, 25.
(Web-01) Pontifical Commission for the Protection of Minors, www.protectionofminors.va, dostęp: 15.01.2018.

(Web-02) Introvigne M., Una verità e tre errori sulla pedofilia nella Chiesa, http://www.lanuovabq.it/ it/articoli-una-verita-e-tre-errori-sulla-pedofilianella-chiesa-15409.htm, dostęp: 15.01.2018.

(Web-o3) Quinto D., Pedofilia sdoganata da un terzo dell'Italia?, http://www.lanuovabq.it/it/articolipedofilia-sdoganata-da-un-terzo-dell-italia-8415. htm, dostęp: 15.01.2018.

(Web-04) Marchesini R., Pedofilia „variante naturale della sessualità umana"?, http://www. libertaepersona.org/wordpress/2011/o4/pedofilia-variante-naturale-della-sessualit-umana-2434, dostęp: 15.01.2018.

(Web-05) Child Dignity in the Digital World World Congress, https://www.childdignity2017. org/it/programme, dostęp: 15.01.2018.

(Web-06) Cernuzio S., Pedofilia sul web, consegnata al Papa la Dichiarazione di Roma, http://www.lastampa.it/2017/10/o6/vaticaninsider/ita/vaticano/ pedofilia-sul-web-lappello-della-dichiarazionedi-roma-a-rischio-la-vita-di-milioni-di-bambini-ilIgR7NZCUmmSk4MqLq6FM/pagina.html, dostęp: 15.01.2018

(Web-07) Cernuzio S., Il final report della Royal Commission sui casi di pedofilia in Australia, http://www.lastampa.it/2017/12/15/vaticaninsider/ ita/nel-mondo/pedofilia-indagine-in-australia-la-chiesa-riveda-celibato-e-segreto-confessionale-Lg ${ }_{3} \mathrm{dG}_{5} \mathrm{PCBqWepTew1CArs//pagina.html,}$ dostęp: 15.01.2018.

(Web-08) Frigerio B., Omertà sulla pedofilia: „La cultura la sta già accettando", http://www.lanuovabq.it/it/omerta-sulla-pedofilia-la-cultura-la-sta-gia-accettando, dostęp: 29.01.2018. 


\section{Paedophilia in Italy: The scale of the problem, ethical aspects and protection of minors}

\section{Abstract}

In recent years, society has been dealing with the rapid development of the global scourge of the sexual exploitation of children, which, according to some findings, has become a new form of slavery. On the one hand, various social initiatives are being launched in many countries with the main goal of combating the sexual exploitation of minors; on the other, the Internet and other modern information technologies give paedophiles new opportunities to interact with children in the virtual world or distribute paedo-pornographic materials. Italy is one of the many countries in which paedophilia has recently become a subject of intense public interest. The main objectives of this article are to outline the causes and specificities of the sexual exploitation of children in Italy and to explore the most important ethical aspects of this phenomenon.

\section{Keywords}

paedophilia, child sexual abuse, paedo-pornography, sexual revolution, sexting, ephebophilia, children's rights, sexual violence, protection of minors 